\title{
Potensi Herbal Antibakteri Cuka Sari Apel terhadap Enterococcus faecalis sebagai Bahan Irigasi Saluran Akar
}

\author{
Rudy Djuanda ${ }^{1}$, Varin Aulia Helmika, ${ }^{2}$ Fiona Christabella ${ }^{2}$, Natallia Pranata ${ }^{3}$, \\ Vinna Kurniawati Sugiaman ${ }^{3 *}$
}

\author{
${ }^{1}$ Departemen Konservasi Gigi, Fakultas Kedokteran Gigi, Universitas Kristen \\ Maranatha \\ ${ }^{2}$ Fakultas Kedokteran Gigi, Universitas Kristen Maranatha \\ ${ }^{3}$ Departemen Oral Biology, Fakultas Kedokteran Gigi, Universitas Kristen \\ Maranatha
}

*email:vvinna.ks@dent.maranatha.edu

\begin{abstract}
Abstrak
Irigasi saluran akar merupakan tahapan penting dalam menunjang keberhasilan perawatan saluran akar. Mikroorganisme paling resisten dan sering ditemukan pada kasus setelah dilakukan perawatan saluran akar adalah Enterococcus faecalis, dengan prevalensi berkisar 24-77\%. Chlorhexidine digluconate dengan konsentrasi $2 \%$ digunakan untuk larutan irigasi saluran akar yang efektif, namun tidak memiliki kemampuan untuk melarutkan jaringan nekrotik. Cuka sari apel memiliki kandungan asam organik yaitu asam asetat dapat yang dapat bertindak sebagai antimikroba yang dapat menyebabkan hilangnya integritas sel. Penelitian ini menguji pengaruh antibakteri, daya hambat, kadar hambat minimum, dan kadar bunuh minimum sediaan cuka sari apel terhadap bakteri Enterococcus faecalis dengan Chlorhexidine digluconate 2\% sebagai kelompok kontrol terhadap pertumbuhan Enterococcus faecalis. Hasil penelitian ini diharapkan dapat menjadi suatu dasar pengembangan cuka sari apel sebagai bahan irigasi saluran akar dan dapat mengetahui aktivitas daya hambat optimum dari sediaan cuka sari apel terhadap bakteri Enterococcus faecalis secara in vitro.

Desain penelitian ini bersifat eksperimental labotratorik secara in vitro menggunakan metode difusi cakram (Tes Kirby-Bauer) dengan pengamatan zona hambat. Data yang diukur adalah diameter zona hambat dari pertumbuhan bakteri Enterococcus faecalis dengan menggunakan jangka sorong dalam satuan milimeter $(\mathrm{mm})$. Kadar bunuh bakteri pada penelitian ini diadaptasi dari metode yang dikembangkan oleh CLSI (Clinical Laboratory Standart Institute, 2014) dengan modifikasi.

Diameter zona hambat cuka apel meningkat seiring dengan peningkatan konsentrasi, bahkan pada konsentrasi minimal 25\% dapat membunuh bakteri Enterococcus faecalis Potensi antibakteri cuka apel setara dengan Chlorhexidine digluconate $2 \%$.
\end{abstract}


SONDE (Sound of Dentistry) Vol 4 No 2

Kata kunci: Cuka apel, Enterococcus faecalis, antibakteri, irigasi saluran akar, KHM, KBM.

\begin{abstract}
Root canal irrigation is an important step in supporting the success of root canal treatment. The most resistant microorganism and often found in cases after root canal treatment is Enterococcus faecalis, with a prevalence ranging from 24-77\%. Chlorhexidine digluconate with a concentration of $2 \%$ is used for an effective root canal irrigation solution, but does not have the ability to dissolve necrotic tissue. Apple cider vinegar contains organic acids, namely acetic acid which can act as an antimicrobial which can cause loss of cell integrity. This study examines the effect of antibacterial, inhibitory, minimum inhibitory, and minimum kill levels of apple cider vinegar preparations against Enterococcus faecalis bacteria with Chlorhexidine digluconate $2 \%$ as a control group on the growth of Enterococcus faecalis. The results of this study are expected to be a basis for the development of apple cider vinegar as a root canal irrigation material and can determine the optimum inhibitory activity of apple cider vinegar preparations against Enterococcus faecalis bacteria in vitro. The design of this research was invitro experimental laboratory using the disk diffusion method (Kirby-Bauer test) with inhibition zone observations. The data measured is the diameter of the inhibitory zone of the growth of Enterococcus faecalis by using calipers in millimeters ( $\mathrm{mm}$ ). The bacterial kill rate in this study was adapted from a method developed by CLSI (Clinical Laboratory Standart Institute, 2014) with modification. Inhibition zone diameter of apple vinegar increases with increasing concentration, even at a minimum concentration of $25 \%$ can kill the bacteria Enterococcus faecalis The antibacterial potential of apple vinegar is equivalent to Chlorhexidine digluconate $2 \%$.
\end{abstract}

Keyword

Apple vinegar, Enterococcus faecalis, antibacterial, root canal irrigation, KHM, KBM. 


\section{Pendahuluan}

Penyakit infeksi pada gigi dan mulut banyak dijumpai di masyarakat dunia khususnya di Indonesia. Menurut Riset Kesehatan Dasar (RISKESDAS) tahun 2018 presentase penduduk Indonesia yang mempunyai masalah gigi dan mulut meningkat dari $25,9 \%$ menjadi $57,6 \%$. Hasil survey menunjukkan prevalensi penyakit gigi dan mulut paling tinggi di Indonesia adalah karies dan penyakit periodontal. ${ }^{1}$

Karies atau gigi berlubang merupakan penyakit yang merusak jaringan keras gigi yaitu enamel, dentin dan sementum yang disebabkan oleh aktivitas asam dari bakteri dan hasil dari fermentasi karbohidrat. ${ }^{2}$ Adapun proses terjadinya karies pada gigi melibatkan beberapa faktor yang saling mempengaruhi yaitu mikroorganisme, host, makanan dan waktu. Karies yang tidak dirawat akan terus berlanjut kerusakannya dan dapat meluas sehingga mengakibatkan penyakit pulpa. ${ }^{3}$

Penyakit pulpa yang paling umum ditemukan dalam kedokteran gigi adalah nekrosis pulpa. Nekrosis pulpa atau disebut juga kematian pulpa merupakan proses lanjutan dari radang pulpa baik akut maupun kronis atau trauma yang menyebabkan terhentinya sirkulasi darah secara tiba-tiba. Nekrosis pulpa yang ditangani dengan ekstraksi merupakan salah satu penyebab hilangnya gigi asli dalam rongga mulut. Kehilangan gigi ini dapat dicegah dengan perawatan saluran akar untuk mempertahankan gigi selama mungkin dalam rongga mulut. ${ }^{4}$

Perawatan saluran akar merupakan prosedur dalam kedokteran gigi yang bertujuan agar gigi yang mengalami kerusakan tetap berfungsi dengan baik dan tidak perlu dicabut. Perawatan saluran akar dapat mengalami kegagalan karena 
berbagai macam keadaan antara lain saat preparasi saluran akar, pengisian saluran akar yang tidak adekuat dan mikroorganisme. Diantara keadaan-keadaan tersebut yang menjadi penyebab utama kegagalan perawatan saluran akar adalah mikroorganisme yang tersisa setelah perawatan ataupun yang muncul setelah dilakukan pengisian saluran akar. ${ }^{5}$

Mikroorganisme dipertimbangkan sebagai penyebab utama adanya kelainan pulpo-periapikal yang persisten dan mempunyai peran penting dalam perjalanan penyakit infeksi pulpa dan periapikal. Mikroorganisme yang banyak ditemukan pada saluran akar yang terinfeksi antara lain Enterococcus faecalis, Streptococcus anginosus, Bacteroides gracilis, dan Fusobacterium nucleatum. Namun yang dikenal paling resisten dan sering ditemukan pada kasus setelah dilakukan perawatan saluran akar adalah Enterococcus faecalis. ${ }^{5}$

Enterococcus faecalis adalah bakteri fakultatif anaerob gram positif yang berbentuk coccus dan dapat tumbuh dengan atau tidak adanya oksigen. Prevalensi perawatan saluran akar yang terinfeksi oleh bakteri Enterococcus faecalis cukup tinggi yaitu berkisar antara $24-77 \%$. Hal ini disebabkan karena berbagai faktor ketahanan dan virulensi dari bakteri Enterococcus faecalis sehingga mampu berkompetisi dengan mikroorganisme lain dalam invasinya ke tubuli dentin termasuk kemampuannya untuk bertahan hidup dalam waktu yang cukup lama ketika nutrisi yang ada sangat sedikit. ${ }^{6}$

Bakteri Enterococcus faecalis ditemukan pada kondisi saluran akar yang telah dilakukan perawatan karena pada saat irigasi atau pembersihan saluran akar kurang bersih. Irigasi saluran akar merupakan tahapan penting dalam menunjang 
keberhasilan perawatan saluran akar, karena dengan irigasi dapat memudahkan jaringan nekrotik, mikroorganisme dan serpihan dentin terbuang keluar dari saluran akar yang terinfeksi. ${ }^{7}$

Irigasi saluran akar bertindak sebagai pelumas dan bertujuan untuk menghilangkan smear layer, bahan irigasi juga bertindak sebagai agen antibakteri yang akan mengeliminasi bakteri pada dinding saluran akar. ${ }^{5}$ Idealnya bahan irigasi memiliki spektrum antimikroba yang luas, mampu melarutkan jaringan nekrotik, mampu menonaktifkan endotoksin pada bakteri dan tidak toksik. ${ }^{8}$ Terdapat beberapa macam bahan irigasi saluran akar yang saat ini popular dan digunakan yaitu salah satunya Chlorhexidine digluconate.

Chlorhexidine digluconate dalam kedokteran gigi telah dikenalkan sejak tahun 1950. ${ }^{9}$ Chlorhexidine digluconate tidak menyebabkan iritasi pada jaringan periapikal, melindungi saluran akar dari kolonisasi mikroorganisme setelah perawatan saluran akar dan baunya tidak menyengat bila dibandingkan dengan larutan irigasi lainnya. ${ }^{10}$

Chlorhexidine digluconate dengan konsentrasi 2\% digunakan untuk larutan irigasi saluran akar sebagai agen antimikroba spektrum luas baik bakteri gram positif maupun gram negatif. Chlorhexidine digluconate 2\% juga digunakan sebagai bahan disinfeksi saluran akar yang efektif terhadap bakteri Enterococcus faecalis. Selain itu, Chlorhexidine digluconate 2\% mempunyai toksisitas yang rendah serta larut dalam air. ${ }^{11}$

Chlorhexidine digluconate 2\% tidak memiliki kemampuan untuk melarutkan jaringan nekrotik, kurang efektif dengan adanya protein dan matriks dentin organik, 
menyebabkan reaksi alergi dan perubahan warna apabila digunakan dalam jangka waktu yang lama secara berulang. Oleh karena itu, dibutuhkan alternatif bahan irigasi saluran akar yang lebih efektif dan juga mudah didapat yaitu dengan memanfaatkan potensi herbal salah satunya adalah apel. ${ }^{12}$

Apel dapat diolah menjadi cuka sari apel yang difermentasi dengan menambahkan bakteri dan ragi ke cairan untuk memulai proses fermentasi alkohol, yang mengubah gula menjadi alkohol dan kemudian alkohol diubah menjadi cuka oleh bakteri pembentuk asam asetat sehingga memiliki keasaman yang relatif rendah. ${ }^{13}$

Cuka sari apel memiliki kandungan asam organik yaitu asam asetat dan asam amino, flavonoid, polifenol serta kaya vitamin dan mineral. Kandungan asam asetat yang dimiliki cuka sari apel bertindak sebagai antimikroba yang dapat menyebabkan hilangnya integritas sel. ${ }^{13}$

Penelitian sebelumnya menunjukkan cuka sari apel teruji mampu menghambat pertumbuhan bakteri Salmonella typhi penyebab demam tifoid dan memiliki pengaruh yang signifikan dikarenakan pada pengujian cuka sari apel dengan konsentrasi $12,5 \%, 25 \%, 50 \%, 75 \%$ dan $100 \%$ zona hambat dari cuka sari apel ini memiliki perubahan yang meningkat, serta memiliki zona hambat yang melebihi Kloramfenikol $30 \mu \mathrm{g}$ sebagai kontrol positifnya pada konsentrasi $25 \%{ }^{14}$

Penelitian ini menguji pengaruh antibakteri, daya hambat, kadar hambat minimum, dan kadar bunuh minimum sediaan cuka sari apel terhadap bakteri Enterococcus faecalis dengan Chlorhexidine digluconate 2\% sebagai kelompok kontrol terhadap pertumbuhan Enterococcus faecalis. Hasil penelitian ini 
diharapkan dapat menjadi suatu dasar pengembangan cuka sari apel sebagai bahan irigasi saluran akar dan dapat mengetahui aktivitas daya hambat optimum dari sediaan cuka sari apel terhadap bakteri Enterococcus faecalis secara in vitro.

\section{Metode Penelitian}

Desain penelitian ini bersifat eksperimental labotratorik secara in vitro menggunakan metode difusi cakram (Tes Kirby-Bauer) dengan pengamatan zona hambat. Data yang diukur adalah diameter zona hambat dari pertumbuhan bakteri Enterococcus faecalis dengan menggunakan jangka sorong dalam satuan milimeter (mm). Kadar bunuh bakteri pada penelitian ini diadaptasi dari metode yang dikembangkan oleh CLSI (Clinical Laboratory Standart Institute, 2014) dengan modifikasi.

Cuka sari apel menggunakan merk B. Larutan cuka sari apel murni diencerkan dengan akuades menggunakan rumus pengenceran $N_{1} \times V_{1}=N_{2} \times V_{2}$ sehingga didapatkan konsentrasi 100\%,75\%, 50\%, 25\%, 12,5\%, dan 6,25\%. Enterococcus faecalis ATCC $^{\circledR} 29212^{\mathrm{TM}}$ murni didapatkan dari Aretha Medika Utama Laboratorium Biomolecular dan Biomedical Research Center, dibiakkan di medium lempeng agar darah.

Data pada penelitian ini akan dilakukan uji normalitas dengan menggunakan uji Saphiro-Wilk karena sampel yang digunakan kecil $(\leq 50)$. Jika data berdistribusi normal dilanjutkan pengujian statistic parametrik yaitu One-Way Anova. Analisis posthoc untuk uji Anova adalah uji Least Significant Difference untuk mengetahui perbedaan yang bermakna dari variasi konsentrasi cuka sari apel dalam 
SONDE (Sound of Dentistry) Vol 4 No 2

menghambat pertumbuhan Enterococcus faecalis dengan menggunakan windows SPSS statistik.

\section{Hasil Penelitian}

Hasil perbandingan uji aktivitas daya hambat cuka apel dengan Chlorhexidine digluconate 2\% terhadap Enterococcus faecalis menunjukkan bahwa semakin tinggi konsentrasi cuka apel yang diberikan (terlihat pada Gambar 1), maka semakin besar zona hambat yang terbentuk. Cuka apel dengan konsentrasi $100 \%$ memiliki zona hambat yang paling besar yaitu $6,47 \mathrm{~mm}$, jika dibandingkan dengan Chlorhexidine digluconate 2\%, DMSO 10\%, maupun denang cuka apel konsentrasi $75 \%, 50 \%, 25 \%, 12,5 \%$, dan $6,25 \%$.

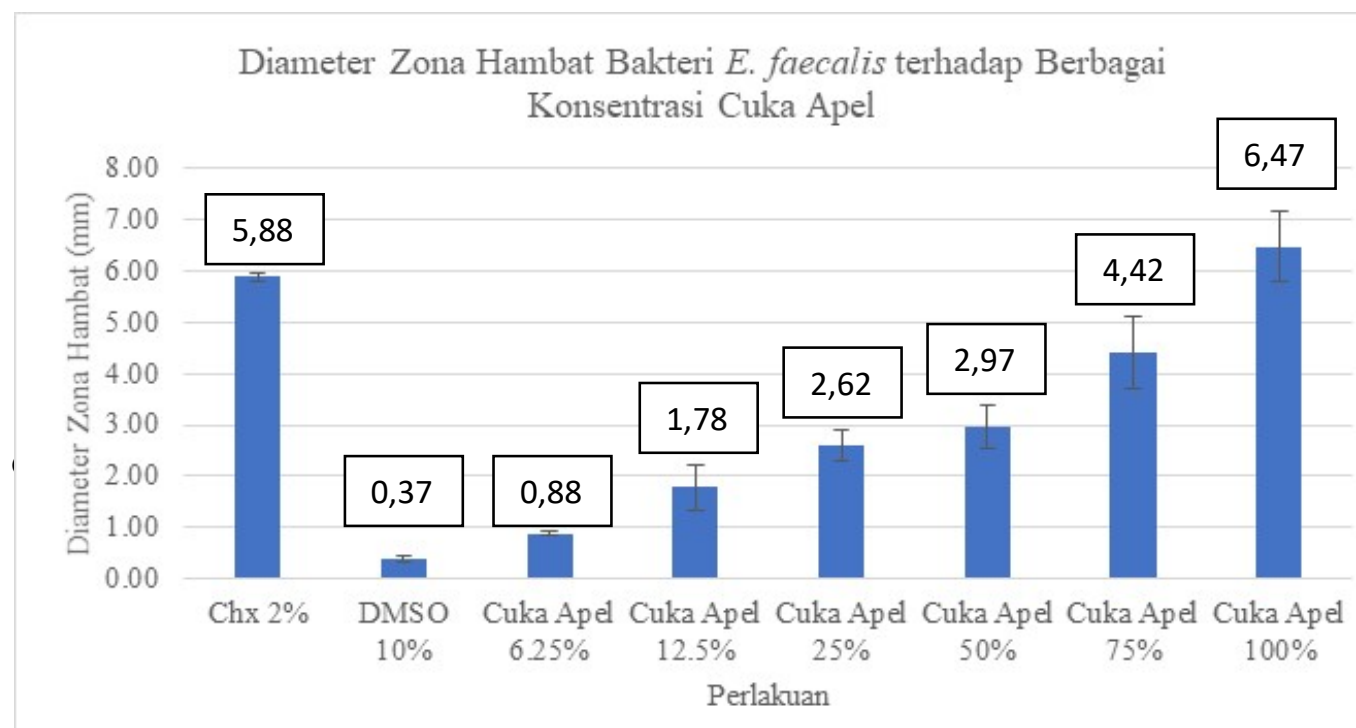

Gambar 1 Rerata Zona Hambat dari Setiap Perlakuan terhadap Pertumbuhan Enterococcus faecalis

Data zona hambat tersebut kemudian di lakukan uji normalitas Saphiro-wilk, didapat nilai $\mathrm{p}<0,05$ sehingga data tidak terdistribusi secara normal. Pada data 
SONDE (Sound of Dentistry) Vol 4 No 2

tersebut dilakukan juga uji homogenitas diperoleh $\mathrm{p}<0,05$. Kesimpulan dari dua pengujian tersebut menyatakan bahwa varian antar kelompok tidak sama atau data tidak homogen. Data hasil penelitian yang tidak terdistribusi normal dan tidak homogen kemudian dilanjutkan analisis data menggunakan IBM SPSS Statistics 22 for Windows. Hasil dari penelitian dianalisis menggunakan analisis non-parametrik uji Kruskal-Wallis, diperoleh nilai $\mathrm{p}=0,002(\mathrm{p}<0,05)$ yang menunjukkan adanya perbedaan antar perlakuan. Pemberian cuka apel dan Chlorhexidine digluconate 2\% memberikan pengaruh yang berbeda terhadap pertumbuhan Enterococcus faecalis, maka dilanjutkan dengan uji Post Hoc Bonferroni untuk mengetahui kelompok yang memberikan perbedaan signifikan dan diperoleh hasil signifikansi $(\mathrm{p}<0,05)$ yang artinya tidak berbeda secara signifikan.

Uji kadar hambat minimum mempunyai tujuan untuk mengetahui kemampuan antimikroba dari sampel pada suatu konsentrasi, yang memiliki aktivitas menghambat pertumbuhan suatu mikroba. Hasil dari uji kadar hambat minimum menggunakan absorbansi dari spektofotometer pada cuka sari apel dapat dilihat pada Gambar 2. Hasil yang bernilai negatif (-) menyatakan tidak adanya pertumbuhan mikroba pada sampel. 


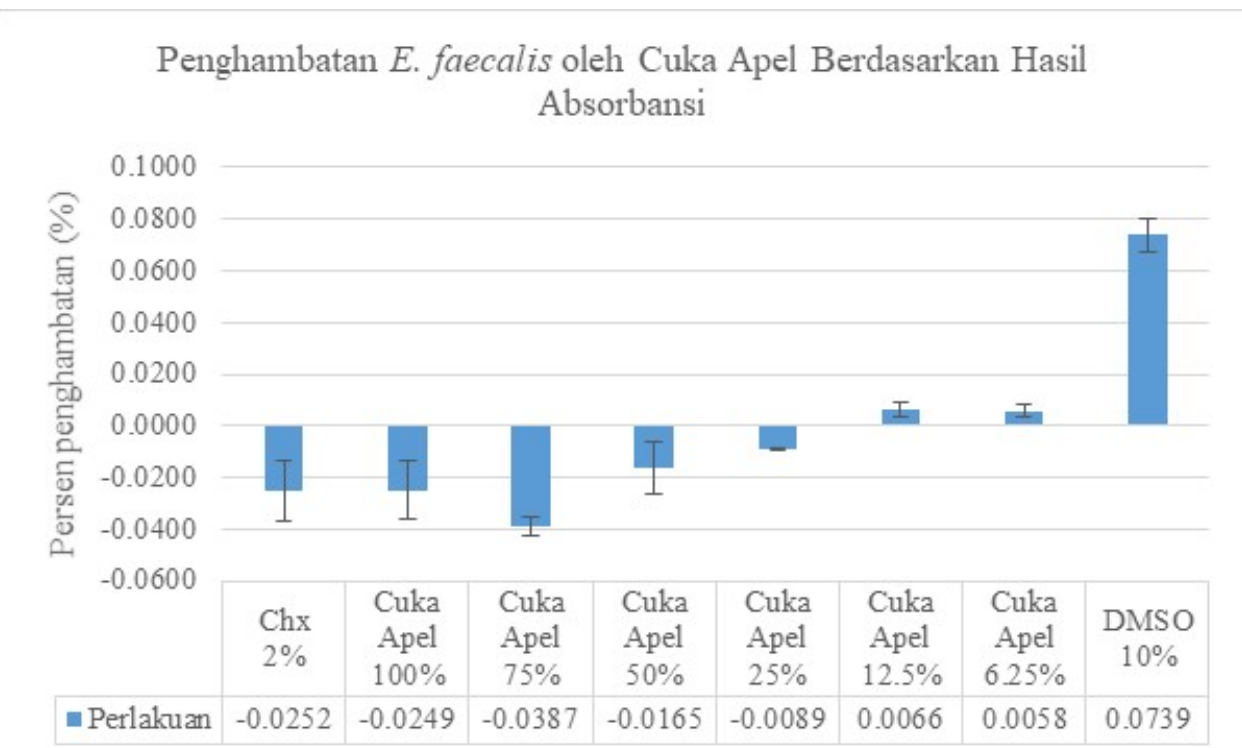

Gambar 2 Absorbansi Sampel setelah Treatment Cuka Apel dan Chlorhexidine $2 \%$ setelah diinkubasi 24 jam.

Pada seluruh perlakuan didapatkan peningkatan nilai absorbansi karena adanya penurunan angka pertumbuhan koloni. Nilai rerata absorbansi tertinggi berada pada konsentrasi larutan cuka apel 100\% (-0,0249), sedangkan nilai absorbansi terendah berada pada konsentrasi larutan cuka apel 6.25\% (0,0058). Konsentrasi larutan cuka sari apel minimum yang mempunyai nilai negatif (-), yang memiliki arti tidak adanya pertumbuhan koloni, berada pada konsentrasi larutan cuka apel $25 \%$.

Uji kadar hambat minimum merupakan uji lanjutan dari kadar bunuh minimum untuk membuktikan ada tidaknya aktivitas antimikroba, dengan pembuktian yang diambil dari pertumbuhan koloni. Hasil pertumbuhan koloni pada suatu pengenceran (konsentrasi) tertentu dapat dilihat pada Tabel 1, 2, dan 3. 
SONDE (Sound of Dentistry) Vol 4 No 2

Tabel 1 Pengamatan Jumlah Koloni

\begin{tabular}{|c|c|c|c|c|c|c|c|c|c|}
\hline \multirow{3}{*}{ Sampel } & \multicolumn{9}{|c|}{ Jumlah Koloni } \\
\hline & \multicolumn{3}{|c|}{$10^{-2}$} & \multicolumn{3}{|c|}{$10^{-4}$} & \multicolumn{3}{|l|}{$10^{-5}$} \\
\hline & 1 & 2 & 3 & 1 & 2 & 3 & 1 & 2 & 3 \\
\hline Kontrol & & & & & & & 148 & 39 & 52 \\
\hline Chx $2 \%$ & & & & & & & & & \\
\hline DMSO 10\% & & & & & & & 79 & 20 & 22 \\
\hline Cuka Apel 6.25\% & & & & 4 & 3 & 2 & & & \\
\hline Cuka Apel 12.5\% & 12 & 9 & 2 & & & & & & \\
\hline Cuka Apel 25\% & & & & & & & & & \\
\hline Cuka Apel 50\% & & & & & & & & & \\
\hline Cuka Apel 75\% & & & & & & & & & \\
\hline Cuka Apel 100\% & & & & & & & & & \\
\hline
\end{tabular}

Tabel 2 Jumlah Bakteri setelah Inkubasi 24 Jam pada Berbagai Konsentrasi Cuka Apel.

\begin{tabular}{lllll}
\hline \multirow{2}{*}{ Sampel } & \multicolumn{3}{l}{ Jumlah Bakteri CFU/mL } & \multirow{2}{*}{ Average } \\
\cline { 2 - 4 } & 1 & 2 & 3 & 159333333.3 \\
Kontrol & 296000000 & 78000000 & 104000000 & - \\
Chx 2\% & - & - & - & - \\
DMSO 10\% & 158000000 & 40000000 & 44000000 & 80666666.7 \\
Cuka Apel 6.25\% & 800000 & 600000 & 400000 & 600000.0 \\
Cuka Apel 12.5\% & 24000 & 18000 & 4000 & 15333.3 \\
Cuka Apel 25\% & - & - & - & - \\
Cuka Apel 50\% & - & - & - & - \\
Cuka Apel 75\% & - & - & - & - \\
Cuka Apel 100\% & - & - & - & - \\
\hline
\end{tabular}

Tabel 3 Penghambatan Pertumbuhan Enterococcus faecalis oleh Cuka Apel

\begin{tabular}{lllll}
\hline \multirow{2}{*}{ Sampel } & \multicolumn{3}{l}{ Penghambatan (\%) } & \multirow{2}{*}{ average } \\
\cline { 2 - 5 } & 1 & 2 & 3 & \\
\hline Chx 2\% & 100.000 & 100.000 & 100.000 & 100.000 \\
DMSO 10\% & 46.622 & 48.718 & 57.692 & 51.011 \\
Cuka Apel 6.25\% & 99.730 & 99.231 & 99.615 & 99.525 \\
Cuka Apel 12.5\% & 99.992 & 99.977 & 99.996 & 99.988 \\
Cuka Apel 25\% & 100.000 & 100.000 & 100.000 & 100.000 \\
Cuka Apel 50\% & 100.000 & 100.000 & 100.000 & 100.000 \\
Cuka Apel 75\% & 100.000 & 100.000 & 100.000 & 100.000 \\
Cuka Apel 100\% & 100.000 & 100.000 & 100.000 & 100.000 \\
\hline
\end{tabular}




\section{Pembahasan}

Cuka apel konsentrasi 100\% dalam menghambat pertumbuhan Enterococcus faecalis memiliki rata-rata zona hambat yang lebih tinggi dibandingkan dengan konsentrasi 6,25\%, 12,5\%, 25\%, 50\%, dan 75\%. Penelitian Hamad (2017) menyatakan bahwa konsentrasi yang lebih tinggi mengakibatkan terjadinya peningkatan tekanan osmosis sehingga cairan akan menuju keluar dari sel bakteri menuju konsentrasi yang lebih rendah memicu pengerutan sel sehingga bakteri menjadi mati karena tidak bisa menjalankan fungsi selnya. Peningkatan konsentrasi akan meningkatkan kandungan senyawa aktif antibakteri sehingga kemampuannya dalam membunuh bakteri semakin meningkat. ${ }^{15}$

Senyawa yang terkandung dalam cuka apel yang paling tinggi yaitu fenol. Golongan fenol mampu merusak membran sel, menginaktifkan enzim dan mendenaturasi protein sehingga permeabilitas dinding menurun dan akhirnya dinding sel mengalami kerusakan. Perubahan permeabilitas membrane sitoplasma memungkinkan terganggunya transportasi ion-ion organic yang penting ke dalam sel sehingga mengakibatkan terhambatnya pertumbuhan sel bahkan hingga kematian sel. Dalam konsentrasi tinggi, kandungan fenol dapat menembus dan mengganggu dinding sel bakteri serta mempresipitasi protein dalam sel bakteri, sedangkan dalam konsentrasi yang lebih rendah, fenol menginaktifkan sistem enzim penting dalam sel bakteri. ${ }^{16}$

Kelompok terbesar dari senyawa fenolik adalah flavonoid. ${ }^{17}$ Flavanoid dalam fungsinya menghambat pertumbuhan Enterococcus faecalis memiliki mekanisme aksi yaitu menghambat sintesis asam nukleat dengan berikatan pada sub unit GyrB 
dari DNA gyrase dan menghambat aktivitas enzim ATPase sehingga DNA bakteri gagal untuk bereplikasi, menghambat fungsi membran sitoplasma bakteri dengan cara meningkatkan permeabilitas inner membran dan kehilangan potensial membran sehingga mengganggu proses gradien elektrokimia proton dalam melewati membran yang penting untuk menjaga kapasitas sintesis ATP, transportasi membran dan pergerakan bakteri. Menghambat metabolisme energi bakteri dengan cara mengubah membran sitoplasma sehingga metabolisme energi dan pertukar nutrisi dari bakteri menjadi terganggu. ${ }^{13,18,19}$

Kandungan dalam cuka apel yang menjadi zat antibakteri adalah asam asetat dan polifenol. Fitokimia turunan polifenol antara lain katekin, kuersetin, phloridzin, dan asam klorogenik. Katekin adalah golongan metabolit sekunder yang dihasilkan oleh tumbuhan dan termasuk golongan flavonoid. Sifat antibakteri dari katekin karena adanya gugus pyrigallol dan gugus galloil. Katekin menghambat bakteri dengan cara merusak membrane sitoplasma bakteri, dimana kerusakan tersebut dapat mencegah masuknya nutrisi yang diperlukan bakteri untuk menghasilkan energy, akibatnya bakteri akan terhambat pertumbuhannya dan mengalami kematian..$^{20,21}$

Kuersetin juga merupakan salah satu zat aktif golongan flavonoid. Aktivitas antibakteri dari kuersetin dapat menyebabkan permeabilitas membran bakteri meningkat. Chusnie dan Lamb (2005) menambahkan bahwa kuersetin juga secara signifikan menghambat motilitas bakteri. Phloridzin termasuk dalam kelompok flavonoid yang menyebabkan kerusakan dinding sel bakteri melalui perbedaan kepolaran antara lipid penyusun DNA bakteri dengan gugus alkohol pada senyawa flavonoid, sehingga dinding sel mengalami kerusakan dan senyawa tersebut dapat 
SONDE (Sound of Dentistry) Vol 4 No 2

masuk ke dalam inti sel bakteri. Asam klorogenik juga mempunyai sifat antibakteri dengan menghambat enzim tertentu yang terlibat dalam sintesis asam lemak bakteri. Selain itu, asam klorogenik secara signifikan dapat meningkatkan permeabilitas membran plasma bakteri yang berakibat pada kebocoran isi sitoplasma termasuk nukleotida. ${ }^{20}$

Asam organik, flavonoid, polifenol dan turunnya yang dimiliki cuka apel dapat menyebabkan terjadinya kerusakan kompleks pada struktur bakteri Enterococcus faecalis sehingga bakteri menjadi lisis. Lisisnya sel bakteri ini menyebabkan kematian sel sehingga tidak terjadi partumbuhan Enterococcus faecalis. ${ }^{22}$

Penelitian ini menggunakan kontrol positif Chlorhexidine digluconate 2\% yang bersifat bakterisid dan bakteriostatik terhadap bakteri gram positif dan gram negatif. Chlorhexidine digluconate $2 \%$ memiliki molekul bermuatan positif yang berikatan dengan molekul bermuatan negatif pada dinding sel bakteri yang akan merusak dinding sel dan mengganggu osmosis. Pada konsentrasi rendah akan mempengaruhi integritas dinding sel. Apabila dinding sel rusak, chlorhexidine digluconate $2 \%$ akan masuk ke dalam sel dan menyerang membran sitoplasma (inner membrane). Kerusakan membran sitoplasma semipermeabel yang halus menyebabkan kebocoran dari komponen sel sehingga sel bakteri menjadi mati. ${ }^{23}$ 
SONDE (Sound of Dentistry) Vol 4 No 2

Cuka apel konsentrasi $100 \%$ lebih tinggi zona penghambatnya dibandingkan dengan Chlorhexidine digluconate $2 \%$ dalam menghambat pertumbuhan Enterococcus faecalis, namun setelah diuji statistik data menunjukkan tidak berdistribusi normal dan tidak berbeda secara signifikan sehingga tidak dapat dikatakan bahwa cuka apel konsentrasi 100\% lebih baik dibandingkan Chlorhexidine digluconate $2 \%$.

Cuka apel berpotensi digunakan sebagai larutan irigasi berbahan herbal karena mengandung senyawa antibakteri yang mampu menghambat Enterococcus faecalis yaitu bakteri pionir penyebab kegagalan perawatan saluran akar. Pada penelitian ini cuka apel diteliti untuk dapat menjadi alternatif larutan irigasi yang sering digunakan untuk mengeliminasi bakteri Enterococcus faecalis yaitu Chlorhexidine digluconate $2 \%$ dan diharapkan dapat menurunkan efek samping dari penggunaan jangka panjang larutan irigasi Chlorhexidine digluconate $2 \%$.

\section{Kesimpulan}

Diameter zona hambat cuka apel meningkat seiring dengan peningkatan konsentrasi, bahkan pada konsentrasi minimal 25\% dapat membunuh bakteri Enterococcus faecalis Potensi antibakteri cuka apel setara dengan Chlorhexidine digluconate $2 \%$. 


\section{DAFTAR PUSTAKA}

1. Departemen Kesehatan Republik Indonesia. Laporan Hasil Riset Kesehatan Dasar (Riskesdas) Nasional 2018. Jakarta: Kementerian Kesehatan RI: 2018

2. Yunita DPS. Pentingnya Kesehatan Gigi dan Mulut dalam Menunjang Produktivitas Atlet. Jurnal Media Ilmu Keolahragaan Indonesia; 2015: 5(1): 13

3. Sri R, Idral P. Peran Makanan Terhadap Kejadian Karies Gigi. Jurnal Kesehatan Masyarakat; 2013: 7(2): 90

4. Khairunnisa, Ichrom MY, Diana S. Toxicity Test of Dayak Onion Bulbs Extract on Artemia Salina Leach Using BSLT Method. Dentino Jurnal Kedokteran Gigi; 2018: 3(1): 91

5. Roy T, Linda R, Paulus BT. Daya Hambat Ekstrak Teripang Emas (Stichopus Hermanii) Terhadap Bakteri Enterococcus Faecalis. Denta Jurnal Kedokteran Gigi; 2015: 9(1): 3

6. Ilham M, Istien W, Linda R. Daya Antibakteri Ekstrak Ikan Teri Jengki (Stolephorus Insularis) Terhadap Enterococcus Faecalis. Denta Jurnal Kedokteran Gigi; 2018: 12(2): 108

7. Ferdio A, Yanuar IN, Lia YB. Efektivitas Daya Hambat Bakteri Ekstrak Bawang Dayak Terstandarisasi Flavanoid Terhadap Enterococcus Faecalis (in vitro). Dentino Jurnal Kedokteran Gigi; 2017: 2(2): 184

8. Kandaswamy D, Venkateshbabu N. Root Canal Irrigant. J Conserv Dent; 2010: 13(4): 264-258

9. Balagopal S, Arjunkumar R. Chlorhexidine: The Gold Standard Antiplaque Agent. J Pharm Sci \& Res; 2013: 5(12): 274-207

10. Maria T. Larutan Irigasi Saluran Akar. Dentofasial; 2010: 9(2): 111

11. Ema M. Peran Bahan Disinfeksi pada Perawatan Saluran Akar. Majalah Kedokteran Gigi; 2011: 18(2): 209-205

12. Mohammadi Z. Chlorhexidine Gluconate its Properties and Applications in Endodontics. Iranian Endod Journal; 2008: 2(4): 125-113

13. Darshna Y, Vlad S, Ajit JS. Antimicrobial Activity of Apple Cider Vinegar against Escherichia coli, Staphylococcus aureus and Candida albicans. Scientific Reports; 2018: 8: 1732 
14. Reza IP, dkk. Efek Antibakteri Cuka Apel Terhadap Salmonella Typhi. Prosiding Penelitian Sivitas Akademika Unisba; 2015: 606-601

15. Mufti N, Bahar E, Arisanti D. Uji Daya Hambat Ekstrak Daun Sawo Terhadap Bakteri E.coli In Vitro. Jurnal Kesehatan Andalas; 2017: 6(2): 295-289

16. Purwantiningsih TI, Suranindyah YY, Widodo. Activity of Phenol of Morinda citrifolia as Natural Antibacteria to Inhibit The Growth of Masitis-Associated Bacteria. Buletin Peternakan; 2014: 38(1): 59-64

17. Hanin NNF, Pratiwi R. Kandungan Fenolik, Flavonoid dan Aktivitas Antioksidan Ekstrak Daun Paku Laut (Acrostichum aureum L) Fertil dan Steril. Journal of Tropical Biodiversity and Biotechnology; 2017: 2: 51-56

18. Cushnie T, Cushnie B, Lamb AJ. Alkaloids: An Overview of Their Antibacterial, Antibiotic Enchancing and Antivirulence Activities. International Journal of Antimicrobial Agents; 2014: 44: 386-377

19. Xie Y, Yang W, Tang F, Chen X. Antibacterial Activities of Flavonoids: StructureActivity Relationship and Mechanism. Current Medicinal Chemistry; 2015: 22: 149-133

20. Putra KK, Setyowati E, Susilorini TE. Inhibition of Malus sylvestris Mill. Peel Extarct Using Etanol Solvent On The Growth of Streptococcus agalactiae and Escherichia coli Causing Masitis. Jurnal Ternak Tropika; 2016: 17(1): 77-85

21. Charde MS, Ahmed A, Chakole RD. Apple Phytochemicals for Human Benefits. Int J Pharm Res; 2011: 1(2): 1-8

22. Sapara TU, Waworuntu O, Juliatri. Efektivitas Antibakteri Ekstrak Daun Pacar Air (Impatiens balsamina L.) Terhadap Pertumbuhan Porphyromonas gingivalis. Jurnal Ilmiah Farmasi; 2016: 5(4): 15-10

23. Kumar SB. Chlorhexidine Mouthwash-A Review. Journal of Pharaceutical Sciences and Research; 2017: 9(9): 1452-1450 